\title{
Interest Rate Exposure and Stocks Returns during Global Financial Crisis: Evidence from Islamic and Conventional Markets
}

\author{
Majid Imdad Khan ${ }^{1 *}$, Waheed Akhter ${ }^{2}$, Usman Bhutta ${ }^{3}$ \\ 1,2,3 Center of Islamic Finance (CIF), Comsats University Islamabad, Lahore Campus
}

\section{Keywords}

Stocks Volatility Interest Rate Exposure

Global Financial Crisis

Dynamic Conditional Correlation

Dow Jones World Islamic Index

Received: 15 January 2020

Accepted: 24 April 2020

\begin{abstract}
This study aims to assess the impact of interest rate change on stocks returns and volatility of Islamic and Conventional stock market indices during global financial crisis for the period from 04 January, 2005 to 30 December, 2015.The stock indices of China (SSE), India (BSE) and Pakistan (PSE) as conventional, and Malaysia (DJIM), Indonesia (JKII) and Dow Jones World Islamic Index (DJWI) (Benchmark) as Islamic markets are employed into consideration, respectively. The volatility and conditional correlation are examined through GARCH $(1,1)$ and Multivariate-DCC GARCH, respectively. The results indicate that Islamic stock indices had low interest rate exposure and less stocks volatility than that of conventional stock indices during the global financial crisis period. This research has important implication for investors that they may consider Islamic stock markets as a safe haven during financial crises.
\end{abstract}

KAUJIE Classification: L41, L43, Q91

JEL Classification: E43, E44, G15, Z12

(c) 2020 JIBM. All rights reserved.

\section{INTRODUCTION}

Islamic finance industry has grown at an exponential rate during the past decade (Merdad, Hasan, \& Hippler, 2015). Islamic stocks are relatively considered less risky and have higher liquidity than conventional stocks (Al-Awadhi \& Dempsey, 2017). The debate on empirical research regarding Islamic markets is growing and predicting the positive/ negative movements of the returns of Islamic and conventional stocks (Aloui, Hammoudeh,\& Hamida, 2015; Rejeb, 2017; Saiti \& Masih, 2016). Global Financial Crisis (GFC) has become an issue due to uncertainty and unexpected situation which harm the economy in term of loss of paper wealth. The volatile and unexpected behavior of stock markets create instability in it

\footnotetext{
${ }^{*}$ Corresponding author: Majid Imdad Khan is a Ph.D scholar at Comsats University Islamabad, Lahore Campus

†Email: Scc.ranamajid@gmail.com
} 
due to interest rate, inflation and exchange rate that result in high risk and financial fragility in markets (Minsky, 1977).

The whole world was affected by the crisis and Asia has no exception. The Asian countries were affected in term of declining demand of goods and services internationally where the growth in exports declined rapidly. The unemployment rate, GDP growth decline, foreign capital flow, FDI and short term foreign institutional investments were reduced in Asia due to decline in exports. The employment rate declined rapidly while the multiplier effects for exports sectors turned negative (Chhibber, Ghosh, \& Palanivel, 2009). It created disturbance in the flow of liquidity which produced volatility in stocks returns in the markets and increased fiscal deficits and debts severely. The difficulties for domestic industries increased with high cost working capital reducing sales and the profit margin. These problems led to lower expected profits and falling valuations which affected the stock markets badly. The credit crises globally in the world and volatility changes in Asian countries were the reflections of poor conditions of the stock markets. The prices of real estate and the exports of India declined sharply during GFC of 2007-2008 (Wade, 2009). From the Asian world, China and India both are the most populous countries, entirely in term of demographic scenario covered effectively on account of GFC, and the neighboring developing countries like Pakistan, Indonesia and Malaysia also had an impact.

As we know, Islamic finance prohibits the interest so, it is expected that Islamic stock indices are less exposed to interest rate volatility as compared to conventional stock indices. Due to Islamic restrictions on interest, the global financial crisis may affect the conventional stock indices more than Islamic stock indices. Earlier studies have attempted to explore the impact of macroeconomic variables along with interest rate change on returns and volatility of Islamic and conventional stock indices and delivers an understanding about conditional correlation for stock returns (Cheong, Nor, \& Isa, 2007; Engle, Ghysels, \& Sohn, 2013; Ibrahim, 2007) for Islamic and conventional stock markets during global financial crisis. The performance of Islamic stock indices and conventional stock indices for different periods have been observed in previous studies (Abu-Alkheil, Khan, Parikh, \& Mohanty, 2017; Bahloul \& Bouri, 2016; Boo, Ee, Li, \& Rashid, 2017; El Mehdi \& Mghaieth, 2017; Hayat \& Hassan, 2017; Narayan \& Banningidadmath, 2017). They have explored performance by using different models but have not evaluated the performance of these indices during financial crises. As far as the financial crisis is concerned, the investment in Islamic stocks is perceived as a safe haven during uncertain times (Raj, 2020). Taking insights about the impact of interest rate exposure and asymmetric market conditions on returns and volatility (Cheong et al., 2007; Ibrahim, 2010; Liau \& Yang, 2008; Nam, Pyun, \& Avard, 2001; Verhoeven \& McAleer, 2004; Wu, 2001; Zhang \& Li, 2008), this study attempts to fill the gap in term of interest rate exposure and conditional volatility effects for Islamic and conventional stock markets. This study takes into account the financial equity markets of Asia i.e. China (SSE), India (BSE) and Pakistan (PSE) as conventional markets and Malaysia (DJIM), Indonesia (JKII) and Dow Jones Islamic World Index (DJWI) as bench mark from Islamic world are taken into consideration to explore the effect of interest rate change on returns and volatility of conventional and Islamic stock markets. 
This study aims to address the following research questions. (i). Does interest rate change have impact on returns and volatility of stock markets? (ii). What other macroeconomic factors along with interest rate change affect the return and volatility of stock markets? (iii) What will be the behavior of conditional correlation of Islamic and Conventional stock indices during global financial crisis? To find the answers of above-mentioned questions, we use GARCH $(1,1)$ modeling to identify the existence and persistence of volatility and effect of macroeconomic variables on returns and volatility of Islamic and conventional stock indices through mean and variance equation. To investigate the effect of interest rate change on the returns and conditional volatility of Islamic and conventional stock indices during global financial crisis, we employed multivariate GARCH-DCC methodology.

This study will be helpful for investors to better investment decisions on the basis of interest rate change and volatility of stock returns. Investors can develop investment criteria in order to select trading time outperformance through risk adjusted basis, hedge ratio and portfolio diversification (Halari, Tantisantiwong, Power, \& Helliar, 2015, Hasan, Hoque, \& Gasbarro, 2017; Oloko, 2017) because Islamic system is used instead of conventional counterparts for investment in order to adopt diversification and financial strength.

The remaining paper is organized as follow: Section II reviews the literature related to interest rate exposure, linearity, non-linearity in stocks and effects of macroeconomic variables during global financial crises. Section III describes the data and Methodology adopted to assess the impact of interest rate exposure on Islamic and conventional stock returns. Section IV provides discussion on results. The last section concludes the paper.

\section{LITERATURE REVIEW}

This study divides the literature in two groups of studies. First group of studies have investigated the impact of interest rate changes in financial and non-financial sectors in various countries across the world (Chen \& Chan, 1989; Christie, 1982; Faff \& Howard, 1999; Ferrando, Ferrer, \& Jareno, 2016; Ferrer, Gonzalez, \& Soto, 2010; Hallerbach, 1994; Jareno, Ferrer, \& Miroslavova, 2016; Joseph \& Vezos, 2006; Memmel, 2011; Oertmann, Rendu, \& Zimmermann, 2000; Olugbode, El-Masry, \& Pointon, 2014; Rashid \& Ahmad, 2008; Shamsuddin, 2014). Consequently, it is worth mentioning here that most of the literature is related to linear interest rate exposure, while little attention has been given to non-linearity.

The relationship between stocks returns of markets and interest rate volatility is presumed negative and commonly driven by financial institutions in markets and macroeconomic variables have effects on companies' value domestically and globally (Oertmann et al., 2000). The capital stock and credit risk are predicted to be a significant components for the interest rate exposure in banking sector and expected risk of interest rate a role with regard to market risk (Ballester, Ferrer, \& Gonzalez, 2010). The real estate and construction industries along with banking are exposed more to interest rate risk and degree of exposure is closely highly leveraged dependent to stability of monetary to manage the interest rate risk (Ballester $e t$ al., 2011). Interest rate exposure was prominent at the time of change in financial system and changes were the result of deregulation, volatility in stock markets, interest rate and exchange rate exposure (Faff \& Howard, 1999). 
The interest rate change may cause the existence of volatility in stocks returns due to mispricing, noise trading and herd behavior; a reason to increase volatility volume rapidly (Bahloul \& Bouri, 2016; Blasco, Corredor \& Ferrer, 2018). The sensitivity of the stock markets of US and Spain with regard to interest rate has also been examined which contributed much attention to explore the effects of interest rate change under bullish, bearish or stable stock markets (Ferrando et al., 2017). Moreover, the risk associated to volatility spillover is sensitive to economic events which change over time (Hamid, Akash, \& Ghafoor, 2019). Of course, a rare work has considered regarding interest rate change and volatility for Islamic stocks.

Islamic sector portfolios were found to be less exposed to interest rate exposure than conventional counterparts (Shamsuddin, 2014). Islamic stocks were less risky than the conventional stocks during crisis period and volatility in stocks was persistent with the bad news and asymmetric pattern but conventional stocks were more sensitive to asymmetric and bad news (Dewandaru, Rizvi, Masih, Masih, \& Alhabshi, 2014; Fakhfekh, Hachicha, Jawadi, Selmi, \& Cheffou, 2016; Usman, Jibran, Amir-ud-Din, \& Akhter, 2019). The contagion effect was weak for Islamic and conventional stocks and small contagion effects were found in developed Islamic markets as compared to leading to developed BRICS countries. BRICS countries were proved best option for portfolio diversification as compared to developed Islamic indices (Kenourgios, Naifar, \& Dimitriou, 2016). Moreover, few studies have investigated the possibility of interest rate exposure complexity than linearity of it. The related studies in this context were explored by Chen and Chan (1989), Benink and Wolff (2000) and Joseph and Vezos (2006) who identify the asymmetric sensitivity of interest rate for US markets.

Second group of studies have investigated the performance of stocks during global financial crisis across different countries in the world (An \& Jin, 2015; Chhibber et al., 2009; Duncan \& Kabundi, 2014; Hong, Lee, \& Tang, 2010; Sohail \& Javed, 2014; Wade, 2009; Wang, 2014).

The evidence is also available regarding transmission of interest rate volatility internationally and co-movements regarding volatility during global financial crisis in relation to Asia in 1997-1998, Brazil in 1999, Russia in 1998 and US in 2000 and 2007-2008 (Duncan \& Kabundi, 2013, 2014). Bad news were showing sever effect on volatility than good news and DJUSI and DJEMI (Islamic indexes) both proved efficient in risk adjustment return of portfolios than conventional counterparts during crisis period (El Mehdi \& Mghaieth, 2017). The crisis was severe in nature in advanced countries as compared to developing due to interdependence level and financial integration. Asian countries were affected through trade and financial channels (Hong et al., 2010). Stock markets were more integrated during shocks and less after crises. Korean markets were more integrated with Japanese markets and degree of integration was high when markets were showing high shocks (Wang, 2014). Depreciation in currency was increased 1\% from Oct, 2004 to Oct, 2007 with US but 36\% from Oct, 2007 to Aug, 2009. Poverty also increased in this period and crisis impact came from UAE and US by fall in remittances, GDP, exports and depreciation in exchange rate (Khawaja, Mahmood, $\&$ Tahir, 2010). Weak linkages were found between markets of Indonesia and developed. 
Developed markets were highly linked with each other for both Islamic and conventional counterparts (Majdoub, Mansour, \& Jouini, 2016). The contagion effect was significant in both the emerging and developed stock markets during GFC and Euro zone crisis. Latin American countries were affected equally as Asian, partially in both the crisis. African and Middle East countries were unaffected during GFC, but partially in Euro zone crisis, while diversification strategies were unaffected during GFC in US stock markets (Mollah, Quoreshi, \& Zafirov, 2015).

Similarly, Ng et al. (2017) found significant volatility, past shocks and leverage effect and the risk evaluations, cross market hedge ratio and risk minimization were proved appropriate for portfolio selection. The time varying effect of macroeconomic factors on stock returns of various sectors in India existed and economic changes were different among the sectors that indicated a message to investors for diversifying the investment (Saji, 2013). The transmission of risk was significant in both Islamic \& conventional counterparts at the time of beginning of 2007 global financial crises. The Islamic stock market could not use hedge strategy for investors as compared to conventional counterparts during financial turmoil. The degree of under and over reaction was declined and averted contagion affect after crisis period in 2007-2009 (Sohail \& Javed, 2014) and the markets were more integrated during the global financial crisis (Lakshmi, Visalakshmi, \& Shanmugam, 2015). On the basis of above literature review, the following hypothesis can be developed.

Hypothesis of Study:

H1: The returns of conventional stock indices are more volatile than Islamic stock indices due to higher interest rate exposure.

\section{DATA AND METHODOLOGY}

In order to assess the impact of interest rate change and volatility on Islamic and conventional stocks, the daily indices of the stock markets of China, India and Pakistan from Asian world and Malaysia and Indonesia from Islamic world have been taken into consideration in this study. Dow Jones Islamic Market Index as Benchmark was taken into consideration to represent the overall Islamic stocks, taken from Yahoo Finance website and DataStream website. The data regarding interest rate, comprised of monthly prices for the period of January 4, 2005 to December 30, 2015 was collected from World Bank website and Econostate.

The returns are calculated as follows:

$r_{i, t}=\ln \left(\frac{p_{t}}{p_{t-1}}\right)$

In the first step residuals were calculated from GARCH model and then moved towards sign bias test as explained under below mentioned regression of squared residuals.

$\epsilon^{n} 2_{t}=\lambda_{0}+\lambda_{1} \operatorname{Sing} z_{t-1}^{-}+\mu_{t} \ldots$

Whereas, Sing $z_{t-1}^{-}=1$ if $\epsilon^{n} 2_{t}<0$ and Sing $z_{t-1}^{-}=0$ otherwise.

The symbol $\lambda_{1}$ is used as coefficient which involves t-test in size bias testing. The coefficient $\lambda_{1}$ will be statistically significant when there is diverse effect on volatility due to positive and negative shocks. The sign and size bias test are used to capture the past shocks 
upon which the volatility depended. Following regression equation can be used.

$\hat{\epsilon}_{t}^{2}=\lambda_{0}+\lambda_{1} \operatorname{Sing} z_{t-1}^{-}+\lambda_{2} \operatorname{Sing} z_{t-1}^{-} \epsilon_{t}^{n}+\lambda_{3} \operatorname{Sing} z_{t-1}^{-} \epsilon_{t}^{n}+\mu_{t} \ldots$

$\operatorname{Sing} z_{t-1}^{+}=1-\operatorname{Sing} z_{t-1}^{-}$

If there would be no correspondence in term of sign and size bias then Null hypothesis will be written as $H_{0} ; \lambda_{1}=\lambda_{2}=\lambda_{3}=0$. This element of test is to be used as Lagrange Multiplier (LM) test.

The mandatory element of model is residual for its repossession regarding variance equation.

In this regard, process of econometric, regarding returns is narrated as under.

$r_{t}=\Psi_{0}+=\sum_{1=1}^{p} \Psi_{i} r_{t-1} \sum_{1=1}^{q} \lambda_{1} \epsilon_{t-1}^{n}+\epsilon_{t}^{n}$

Where $\Psi_{0}$ is constant, $\Psi_{i} \lambda_{1}$ and are the parameters, $r_{t}$ is denoted for return at time $t$ and $\epsilon_{t}^{n}$ is denoted as white noise at time t. ARMA (p, q) model in equation (3) which explores that returns are dependent on returns and shocks at previous values.

The understandability of ARCH model can only be assisted in term of first order auto regression as indicated in the following equation.

$r_{t}=\alpha r_{t-1}+\epsilon_{t}^{n}$

The function of residuals at historical can be perceived in term of conditional mean denoted as $\delta$ which indicates as conditional variance. The prediction may be improved through equation if the historical information in variance equation should be absorbed. Engle (1982) explored the model as under:

$\delta t 2=\alpha 0+\alpha 1 r_{t-12}+\epsilon_{t}^{n}$

Where $\epsilon_{t}^{n} \operatorname{iid}(0,1)$., Engle (1982) proposed a method to parameterize i.e. $\delta t 2$ in order to investigate the behavior in term of heteroscedasticity. $\delta t 2=\alpha 0+\sum \alpha i q i \ldots \ldots \ldots \ldots \ldots \ldots$ ........(7)

Where $\alpha 0>0$ and $\alpha 0 \geq 0$.

Bollerslev (1986) proposed GARCH model which is the generalized form of ARCH model (Engle, 1982). The non-negative constraint is considered in a better way with GARCH model and superior fit as compared to ARCH model which permits conditional variance, modeled by numbers of lagged values along historic shocks. GARCH (p, q) model is explained as equation under.

$\delta t 2=\Psi_{0}+\sum \Psi i q i=\epsilon_{t}^{n}-i 2+\sum \gamma j p j=1 \delta t 2-j$ 
Whereas, order of GARCH and ARCH terms are represented as p, q respectively. Conditional variance at time $t$ denoted as $\lambda t 2, \Psi 0$ is denoted as constant, parameters are denoted as $\Psi i$ and $\gamma j . \epsilon_{t}^{n}-i 2$ is the preceding square shocks indicator. $\Delta t 2-j$ expressed as variance at previous indicator.

Brooks (2008) explored GARCH $(1,1)$ in most cases and investigated that it is enough to predict clustering volatility. Moreover, he indicated that it as unique case in finance studies because of having very exceptional use in term of higher order. Thick tailed returns and clustering volatility in GARCH $(1,1)$ model are successfully investigated in terms of diverse number of financial time series. The condition i.e. $(\alpha+\beta<1)$ which fulfilled the requirement of stationarity of data in $\operatorname{GARCH}(1,1)$ model if on the other side if the condition i.e. $(\alpha+\beta=1)$ in process but said to be stationary due to infinite variance. If average value is zero then is considered as distributed normally and $\left(\epsilon_{t}^{n} \sim N(0, \delta t 2)\right)$ is expressed in time varying variance.

Engle (2002) explored the model of multivariate GARCH-DCC in order to employ the volatility regarding time-varying estimation and interdependence among series of returns. This model gives the output in term of volatility changes and interdependence over time. Specifically it defines the direction or movement of the output either positive/negative and strong/weak magnitude. The multivariate GARCH-DCC-model by Engle's (2002) is an improved form of the estimator (CCC) constant conditional correlation of Bollerslev (1990) which involved two steps as under.

The step (01) is the estimation of an individual stock index regarding conditional variance where a univariate GARCH $(1,1)$ model, observed under k numbers for series of returns can be used as under.

$h_{i t}=v_{j}+\sum_{x=1}^{x i} \alpha_{j x} r^{2} i t-x+\sum_{z=1}^{z j} \beta_{j y} h_{i t-y}$, For $j=1,2,3$

Whereas, $v_{j}, \alpha_{j x}$ and are elements which are non-negative $\sum_{x=1}^{x j} \alpha j x$ and $\sum_{x=1}^{z j}$ and $\beta_{j y}$ $<1$. $h_{i t}$ is denoted as the estimation of conditional variance regarding asset individually, $\alpha j x$ is denoted as shocks for short term returns for $\chi$ (ARCH effect) and $\alpha j y$ is denoted as shocks for returns $Y$, persistent to effect of GARCH in long run. In this regard, the specification of Engle's-DCC-model is further extended as under:

$$
\begin{aligned}
& D_{t}=\operatorname{diagonal}\left(\sqrt{\omega_{11, t}}, \sqrt{\omega_{22, t}}\right) \\
& \hat{R}_{t}=\dot{O}_{t}^{*-1} \dot{O}_{t} \hat{O}_{t}^{*-1} \ldots \ldots \ldots \ldots \ldots \ldots
\end{aligned}
$$

Whereas, $k x k$ explored as asymmetric positive definitive matrix and $O_{t}^{\prime}=q_{i j, t}$ is calculated as:

$$
\dot{O}_{t}=(1-\theta-\lambda) \dot{O}^{\prime} \lambda O_{t-1}^{\prime} \theta \sigma_{i, t-1} \sigma_{j, t-1} \ldots \ldots \ldots \ldots \ldots
$$

Whereas, the $(k, k)$ time varying covariance matrix for standardized residuals is denoted by $O^{\prime} t$ and unconditional correlation by $O^{\prime \prime}$ of $\theta_{i t}, \theta_{j, t}$ and scalar parameters which are 
non-negative are indicated by $\varphi$ and $\lambda$ which fulfill $\varphi+\lambda<1$..

In this regard the market $X$ and $Z$ under conditional correlation at time $\mathrm{t}$ can be observed as under.

$\left.\rho_{i, j, t}=(1-\theta-\lambda) \bar{\rho}_{i j}\right)+\theta \sigma_{j, t-1} /\left[\left((1-\theta-\lambda) \bar{q}_{i j}+\theta \sigma_{i, t-1}^{2}+\lambda q_{i i, t-1}\right]^{1 / 2}[(1-\theta-\lambda)+\right.$ $\left.\bar{q}_{i j}+\theta \sigma_{i, t-1}^{2} q_{i i, t-1}\right]^{1 / 2}$

Whereas, the element for matrix $O_{t}^{\prime}$ at $i^{t h}$ row and $j^{t h}$ is denoted as $q_{i j}$, an assumption of Gaussian, the parameters regarding conditional log likelihood, introduced by Bollerslev (1988), is explained as follows.

$L K=-\frac{1}{2} \sum\left[\left(K \log (2 \pi)+\log \left|D_{t}\right|^{2}+\epsilon_{t} D_{t}^{-1} D_{t}^{-1} \epsilon_{t}\right)\left(\log \left|\hat{R}_{t}\right| \sigma_{t} \hat{R}_{t}^{-1} \sigma_{t}-\sigma_{t} \sigma_{t}\right)\right] \ldots \ldots \ldots(14)$

RESULTS AND DISCUSSION

TABLE 1

Descriptive Statistics of Stock Market Returns; For the Period from 04 Jan, 2005 to 31 Dec, 2015

\begin{tabular}{lllllll}
\hline \hline & Conventional Stock & \multicolumn{5}{l}{ Islamic Stock } \\
\hline & SSE & BSE & PSE & DJIM & JKII & DJWI \\
\hline Mean & 0.0003 & 0.0005 & 0.0007 & 0.0003 & 0.0005 & 0.0002 \\
Median & 0.0003 & 0.0009 & 0.0110 & 0.0000 & 0.0007 & 0.0003 \\
Maximum & 0.0903 & 6.9078 & 0.0825 & 0.0463 & 0.3579 & 0.0983 \\
Minimum & -0.0926 & -6.9269 & -0.0604 & -0.1094 & -0.1782 & -0.0842 \\
Std. Deviation & 0.0175 & 0.1774 & 0.0128 & 0.0077 & 0.0176 & 0.0101 \\
Skewness & -0.4709 & -0.1813 & -0.4106 & -1.2422 & 2.2513 & -0.4464 \\
Kurtosis & 7.0111 & 1496.5 & 6.2075 & 22.2104 & 67.5565 & 14.8376 \\
Jarque-Bera & 2187.0840 & 287000000.00 & 1412.3460 & 48340.170 & 539531.60 & 18156.070 \\
Probability & 0.0000 & 0.0000 & 0.0000 & 0.0000 & 0.0000 & 0.0000 \\
\hline \hline
\end{tabular}

Table 1 explains the results of descriptive statistics regarding daily returns of conventional and Islamic stock markets. It covers the period from 04 Jan, 2005 to 30 Dec, 2015. The stock markets are Shanghai Stock Exchange (SSE)-China, Bombay Stock Exchange (BSE)-India, Pakistan Stock Exchange (PSE)-Pakistan, Dow Jones Islamic Market Malaysia (DJIM)Malaysia, Jakarta Islamic Index (JKII)-Indonesia and Dow Jones World Islamic Index (DJWI). The stocks of PSE generated higher average returns but SSE and BSE stocks remained riskier. SSE, BSE, PSE, DJIMI and DJWI are negatively skewed but DJIM remained positively skewed. Jarque Bera normality test confirms exodus from normality regarding all the returns of market and shown in below graphs that the returns are fluctuating during crisis, after crisis and pre-crisis period. 

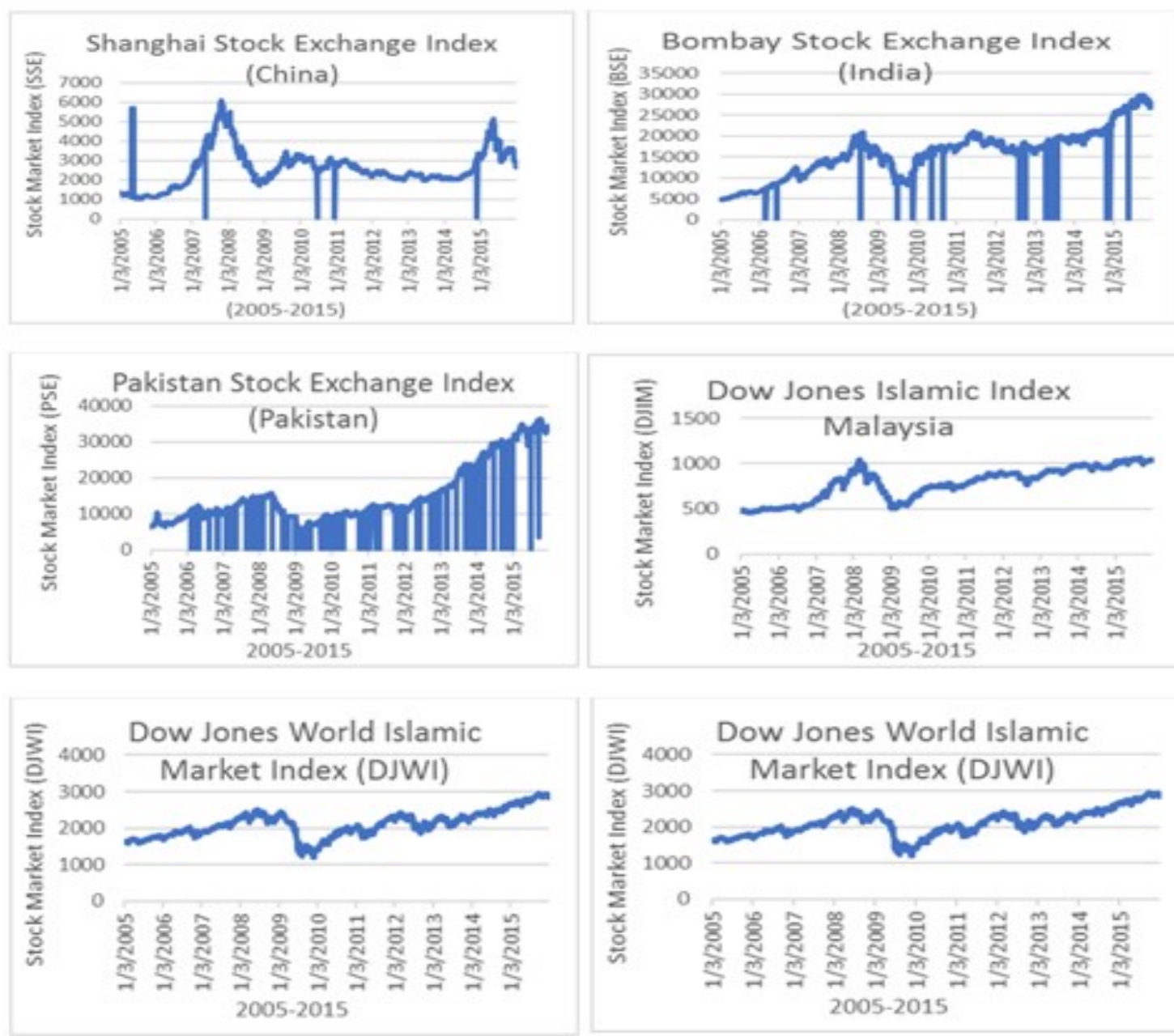

FIGURE 1. Plots of stock market returns of SSE, BSE, PSE, DJIM, JKII and DJWI

Figure 01 shows the plots of Islamic and conventional stock market indices for the period from Jan, 2005 to Dec, 2015. The trends of the plots indicate that the return indices of Islamic and conventional stock markets are fluctuating during the period of crisis, pre-crisis and post crisis period. The SSE indices are increasing at the start of 2007 and decreasing after 2008 rapidly, BSE is increasing from 2006-2008 and then decreasing after the mid of 2008. The trend of PSE is also decreasing after the mid of 2008. The DJIM and JKII indices are decreasing after 2008 while DJWI indices start decreasing after 2009. The fluctuations in Islamic and conventional indices of stock markets suggest that the global financial crisis had impact on Islamic stock market, but less as compared to conventional stock market indices.

Table-2 explains the results of descriptive statistics regarding monthly returns of interbank offered rates, proxy of interest rate of 05 countries (China, India, Indonesia, Malaysia and Pakistan). The returns of China (IBOR), India (IBOR) and Indonesia (IBOR) found positive on average except Pakistan (IBOR) and Malaysia (IBOR). China and Malaysia returns are negatively skewed but returns of India, Pakistan and Indonesia positively skewed. The normality of series confirms from normality test Jarque-Bera which explored that the series are not normal regarding all the returns of interbank offer rate of all countries as shown in below graphs that the return series of interbank offered rates are fluctuating during crisis, after crisis and pre-crisis period. 
TABLE 2

Descriptive Statistics of Monthly Returns of Interbank Offer Rates of China, India, Pakistan, Malaysia and Indonesia; For the Period from 04 Jan, 2005 to 31 Dec, 2015

\begin{tabular}{llllll}
\hline \hline & China & India & Pakistan & Malaysia & Indonesia \\
\hline Mean & 0.0103 & 0.0019 & -0.0016 & -0.0001 & 0.0019 \\
Median & 0.0105 & 0.0000 & 0.0000 & 0.0000 & 0.0002 \\
Maximum & 0.6025 & 0.2559 & 0.2179 & 0.0746 & 0.1335 \\
Minimum & -0.7467 & -0.0789 & -0.1408 & -0.1116 & -0.1265 \\
Std. Deviation & 0.1741 & 0.0339 & 0.0505 & 0.0209 & 0.0445 \\
Skewness & -0.3945 & 5.1211 & 0.3222 & -1.5407 & 0.3005 \\
Kurtosis & 7.4422 & 35.9709 & 6.8679 & 14.3699 & 3.9070 \\
Jarque-Bera & 111.1048 & 6506.2480 & 83.9271 & 757.4519 & 6.4626 \\
Probability & 0.0000 & 0.0000 & 0.0000 & 0.0000 & 0.0000 \\
\hline \hline
\end{tabular}
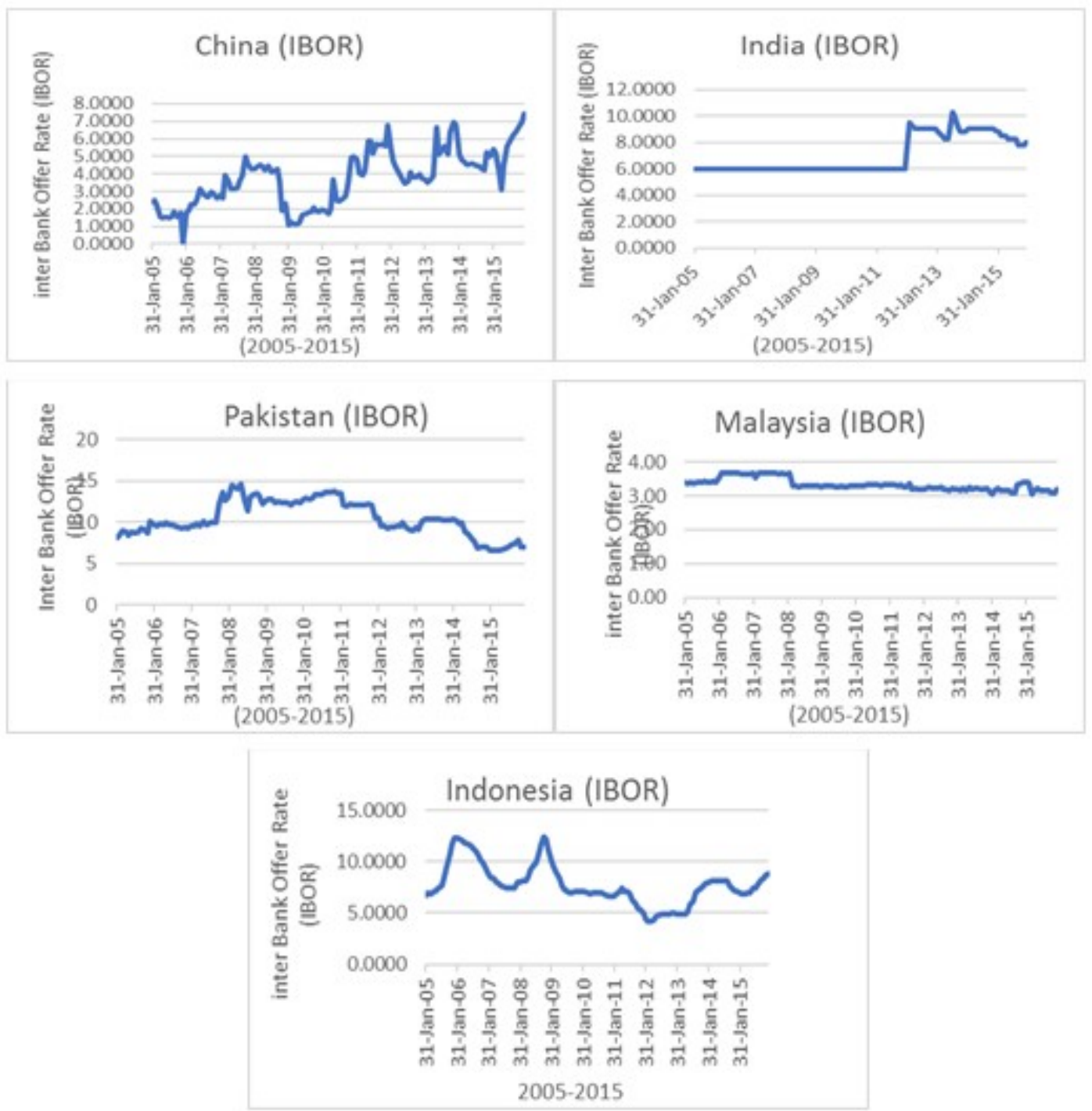

FIGURE 2. Plots of returns of interbank offer rates of China, India, Pakistan, Malaysia and Indonesia 
Figure 02 shows the plots of interbank offer rates (IBOR) of China, India, Indonesia, Malaysia and Pakistan for the period from Jan, 2005 to Dec, 2015. The trends of the plots of IBOR indicate the fluctuations during global financial crisis, pre-crisis and post crisis period. The IBOR of China decreased rapidly after 2008 but IBOR of India remained stable during global financial crisis of 2007-2008. The IBOR of Pakistan initially decreased slightly till 2008 and then increased after that then decreasing again after 2008. The IBOR of Malaysia was slightly decreasing after 2007 but remained stable after that. The IBOR of Indonesia also decreased after 2007 and then increased after 2008. Overall plots show that the fluctuations in IBOR of all the countries indicate the effects of global financial crisis on all except India.

TABLE 3

Estimation of Sign and Size Bias (SB) Test

\begin{tabular}{lllllll}
\hline \hline \multicolumn{3}{l}{ Conventional Stock } & \multicolumn{4}{l}{ Islamic Stock } \\
\hline & SSE & BSE & PSE & DJIM & JKII & DJWI \\
SB-T & 0.00002 & -0.00008 & -0.00003 & 0.00008 & $-0.00055^{* *}$ & 0.00008 \\
NSB-T & $-0.00920^{* *}$ & $-0.03347^{* *}$ & $-0.01981^{* *}$ & $-0.00223^{* *}$ & $-0.07625^{* *}$ & $-0.0186^{* *}$ \\
PSB-T & $0.00807^{* *}$ & $0.00904^{* *}$ & $0.00946^{* *}$ & $0.01549^{* *}$ & $0.00192^{* *}$ & 0.00588 \\
\hline \hline
\end{tabular}

Table 3 reports the results of sign and size bias test for conventional and Islamic stock indices where these were found positive and negative respectively at significance level of $5 \%$. The markets are perceived significant with respect to NSB (negative sign bias) and PSB (positive sign bias) which means that the conventional and Islamic stock markets are showing asymmetric behavior. The results further reveal that the PSB and NSB are significant for all the conventional and Islamic stock markets except DJIM. Overall results explore that the returns series regarding all the markets showing asymmetric behavior but the DJIM rejected the null hypothesis. The non-linear trend was observed in return series, confirmed by Sign and Size bias test at 5\% significance level.

TABLE 4

Estimation of GARCH $(1,1)$ Model

\begin{tabular}{|c|c|c|c|c|c|c|c|}
\hline & & \multicolumn{3}{|c|}{ Conventional Stock } & \multicolumn{3}{|c|}{ Islamic Stock } \\
\hline Statistics & Parameters & SSE & BSE & PSE & DJIM & JKII & DJWI \\
\hline Mean & & 0.0005 & $0.0014 * *$ & $0.0145 * *$ & 0.0004 & $0.0016 * *$ & $0.0015 * *$ \\
\hline Equation & & 0.0428 & $0.0947 * *$ & $0.0825 * *$ & $0.1873 * *$ & $0.1114 * *$ & $0.1131 * *$ \\
\hline Variance & & $0.0002 * *$ & $0.0001 * *$ & $0.0003 * *$ & $0.00005^{* *}$ & $0.00000082 * *$ & $0.00003 * *$ \\
\hline Equation & & 0.0705 & $0.1458 * *$ & $0.1785^{* *}$ & $0.1935 * *$ & $0.67719 * *$ & $0.1498 * *$ \\
\hline & & $0.9350 * *$ & $0.9652 * *$ & $0.8749 * *$ & $0.6399 * *$ & $0.7875^{* *}$ & $0.9129 * *$ \\
\hline Diagnostic Testing & AIC-Statistics & -5.49058 & -5.52988 & -5.49048 & -6.38487 & -5.92674 & -5.66108 \\
\hline
\end{tabular}

Table 4 estimates GARCH model regarding coefficient of conditional mean equation where p-value $<0.00001$ and significant except SSE for conventional stock indices and Islamic stock indices. The confidence interval at $95 \%$ was significant in term of ARCH where current volatility regarding all markets is influenced by behavior of past price. The 
persistence regarding volatility at confidence interval of $95 \%$ perceived as significant in term of GARCH. Coefficient of stock returns, lagged which observed significant where $p<0.005$ that predicted that current volatility is affected significantly by volatility of lagged. Both the coefficients and are predicted significantly where $\mathrm{p}<0.00001$ which indicated that hypothesis in term of constant variance is rejected. The model selection criteria applied in term of usage of methods i.e. AIC, Schwarz and Log likelihood.

TABLE 5

Estimation of Multivariate GARCH-DCC between SSE, BSE, PSE, DJIM, JKII and Interbank Offer Rate (IBOR) of All Countries.

\begin{tabular}{llccc}
\hline \hline Index & DCC-Coeff & Pre-Crisis (2005-2008) & Crisis Period (2008) & Post Crisis (2009-15) \\
\hline SSE & DCC (1) & $0.0070^{*}$ & Interest Rate \\
& & -0.0042 & 0.0231 & $0.0158^{*}$ \\
& DCC (2) & $0.9308^{* * *}$ & -0.0094 & -0.0086 \\
& & -0.0065 & $0.8795^{* * *}$ & $0.9490^{* * *}$ \\
BSE & DCC (1) & $0.0088^{* *}$ & -0.1055 & -0.0259 \\
& & -0.0049 & 0.0263 & 0.0136 \\
& DCC (2) & $0.9867^{* * *}$ & -0.0164 & -0.0079 \\
& & -0.0076 & $0.7868^{* * *}$ & $0.9843^{* * *}$ \\
PSE & DCC (1) & $0.0047^{* * *}$ & -0.2267 & -0.0303 \\
& & -0.0038 & 0.0104 & $0.0195^{* * *}$ \\
& DCC (2) & $0.9265^{* * *}$ & -0.0076 & -0.0094 \\
& & -0.008 & $0.8261^{* * *}$ & $0.9837^{* * *}$ \\
DJIM & DCC (1) & $0.0078^{*}$ & -0.067 & -0.0531 \\
& & -0.005 & 0.0304 & 0.0148 \\
& DCC (2) & $0.9847^{* * *}$ & -0.0162 & -0.0098 \\
& & -0.0071 & $0.8402^{* * *}$ & $0.9261^{* * *}$ \\
JKII & DCC (1) & 0.0044 & -0.2869 & -0.0405 \\
& & -0.0038 & 0.0108 & $0.0172^{* *}$ \\
& DCC (2) & $0.9539^{* * *}$ & -0.0093 & -0.0072 \\
& & -0.0088 & $0.8693^{* * *}$ & $0.9450^{* * *}$ \\
\hline \hline
\end{tabular}

Table 5 explores the results of Multivariate GARCH-DCC where the Coefficients of indices and interest rates of China, India, Indonesia, Malaysia and Pakistan. DCC-1 represents indices whereas DCC-2 represents interest rate. China stock indices and its interest rate are significant and positive during the pre-crisis, during crisis and post crisis periods. The values are $0.0070,0.0230$ and 0.0158 respectively. Coefficients show that the magnitude of coefficients of volatility is smaller during pre-crisis period and post crisis period than that of during crisis. In addition, the coefficients of Indian, Pakistani (Conventional) and Malaysian and Indonesian stock market (Islamic) indices and interest rate are also significant and positive during pre-crisis, during crisis and post crisis periods. Coefficients of indices and interest rates show that the magnitude of coefficients of volatility are smaller during pre-crisis and post crisis periods than that of during crisis period. 


\section{CONCLUSION}

This research explores the effects of global financial crises and interest rate changes in terms of conditional correlation volatility of Islamic and conventional stock indices. The coefficients of China stock market indices and interest rate remained significant and positive in the precrisis, crisis and post crisis periods. Coefficients show that the magnitude of volatility was smaller during pre-crisis period and post crisis period than that of during crisis. In addition, the coefficients regarding Indian, Pakistan (Conventional) and Malaysian and Indonesian stock market (Islamic) indices and interest rate were significant and positive during the precrisis, during crisis and post crisis periods. Coefficients show that the magnitude of volatility was smaller during pre-crisis period and post crisis period than that of during crisis period. Overall conclusion suggested that there was no effect of interest rate change on stock indices of DJIM. On the basis of this study, the investors can invest their funds in better stocks from conventional and Islamic indices. They can manage the risk of any global financial crisis by investing in Islamic stocks rather than conventional stocks. The investment strategies for investors may be fruitful because they can lessen the risk and manage the investment in models of performance oriented and reasonable businesses. This research may be helpful for Government and policy makers to develop policies for businesses and investors. The policy makers may introduce policies to promote Islamic stocks and Sharí'ah governing laws in business enterprises. Government may take steps to reduce the volatility which is a measure of risk for Islamic and conventional stocks. The volatility and crisis effect, if identified through best modeling selection, could identify the risk-return behavior of conventional and Islamic stock market indices and interest rate change in better way for excellent solution in future.

This study also provides directions for further research. The researchers may take larger sample of countries and expand this research to other regions or sub-regions e.g. Middle East, GCC, Europe etc. They may compare Islamic and conventional stock indices of the same country. Generally, conventional stock index also includes some of the top performing Islamic stocks by default, which may dilute the results of comparison. Future researchers may focus on developing an index that can isolate the conventional stock index from the effects of Islamic stock.

\section{REFERENCES}

Abu-Alkheil, A., Khan, W. A., Parikh, B., \& Mohanty, S. K. (2017). Dynamic co-integration and portfolio diversification of Islamic and conventional indices: Global evidence. The Quarterly Review of Economics and Finance, 66, 212-224.

doi: https://doi.org/10.1016/j.qref.2017.02.005

Al-Awadhi, A. M., \& Dempsey, M. (2017). Social norms and market outcomes: The effects of religious beliefs on stock markets. Journal of International Financial Markets, Institutions and Money, 50, 119-134. doi: https://doi.org/10.1016/j.intfin.2017.05.008

Aloui, C., Hammoudeh, S., \& Hamida, H. B. (2015). Co-movement between sharia stocks and sukuk in the GCC markets: A time-frequency analysis. Journal of International 
Financial Markets, Institutions and Money, 34, 69-79.

doi: https://doi.org/10.1016/j.intfin.2014.11.003

Jin, X., \& An, X. (2016). Global financial crisis and emerging stock market contagion: A volatility impulse response function approach. Research in International Business and Finance, 36, 179-195. doi: https://doi.org/10.1016/j.ribaf.2015.09.019

Bahloul, W., \& Bouri, A. (2016). The impact of investor sentiment on returns and conditional volatility in US futures markets. Journal of Multinational Financial Management, 36, 89-102. doi: https://doi.org/10.1016/j.mulfin.2016.07.003

Ballester, L., Ferrer, R., \& Gonzalez, C. (2009). Impact of interest risk on the shares of the Spanish banking sector. Spanish Journal of Finance and Accounting, 38(142), 213-237. doi: https://doi.org/10.1080/02102412.2009.10779667

Benink, H. A., \& Wolff, C. C. (2000). Survey data and the interest rate sensitivity of US bank stock returns. Economic Notes, 29(2), 201-213. doi: https://doi.org/10.1111/1468-0300.00030

Boo, Y. L., Ee, M. S., Li, B., \& Rashid, M. (2017). Islamic or conventional mutual funds: Who has the upper hand? Evidence from Malaysia. Pacific-Basin Finance Journal, 42, 183-192. doi: https://doi.org/10.1016/j.pacfin.2016.01.004

Blasco, N., Corredor, P., \& Ferrer, E. (2018). Analysts herding: when does sentiment matter?. Applied Economics, 50(51), 5495-5509. doi: https://doi.org/10.1080/00036846.2018.1486999

Cheong, C. W., Nor, A. H. S. M., \& Isa, Z. (2007). Asymmetry and long-memory volatility: Some empirical evidence using GARCH. Physica A: Statistical Mechanics and its Applications, 373, 651-664. doi: https://doi.org/10.1016/j.physa.2006.05.050

Chhibber, A., Ghosh, J., \& Palanivel, T. (2009). The global financial crisis and the AsiaPacific region. UNDP Regional Centre for Asia and the Pacific, Colombo, Sri Lanka.

Chen, C. R., \& Chan, A. (1989). Interest rate sensitivity, asymmetry, and the stock returns of financial institutions. Financial Review, 24(3), 457-473. doi: https://doi.org/10.1111/j.1540-6288.1989.tb00352.x

Christie, A. A. (1982). The stochastic behavior of common stock variances: Value, leverage and interest rate effects. Journal of financial Economics, 10(4), 407-432. doi: https://doi.org/10.1016/0304-405X(82)90018-6

Dewandaru, G., Rizvi, S. A. R., Masih, R., Masih, M., \& Alhabshi, S. O. (2014). Stock market co-movements: Islamic versus conventional equity indices with multi-timescales analysis. Economic Systems, 38(4), 553-571. doi: https://doi.org/10.1016/j.ecosys.2014.05.003

Duncan, A. S., \& Kabundi, A. (2013). Domestic and foreign sources of volatility spillover to South African asset classes. Economic Modelling, 31, 566-573. doi: https://doi.org/10.1016/j.econmod.2012.11.016

Duncan, A. S., \& Kabundi, A. (2014). Global financial crises and timeâǍ ̌̌varying volatility comovement in world equity markets. South African Journal of Economics, 82(4), 531-550. doi: https://doi.org/10.1111/saje.12033 
Olugbode, M., ElâĂ̌̌Masry, A., \& Pointon, J. (2014). Exchange rate and interest rate exposure of UK industries using firstâĂŘorder autoregressive exponential GARCH-inmean (EGARCH-M) approach. The Manchester School, 82(4), 409-464. doi: https://doi.org/10.1111/manc.12029

El Mehdi, I. K., \& Mghaieth, A. (2017). Volatility spillover and hedging strategies between Islamic and conventional stocks in the presence of asymmetry and long memory. Research in International Business and Finance, 39, 595-611.

doi: https://doi.org/10.1016/j.ribaf.2016.04.006

Engle, R. F., Ghysels, E., \& Sohn, B. (2013). Stock market volatility and macroeconomic fundamentals. Review of Economics and Statistics, 95(3), 776-797. doi: https://doi.org/10.1162/REST_a_00300

Fakhfekh, M., Hachicha, N., Jawadi, F., Selmi, N., \& Cheffou, A. I. (2016). Measuring volatility persistence for conventional and Islamic banks: An FI-EGARCH approach. Emerging Markets Review, 27, 84-99. doi: https://doi.org/10.1016/j.ememar.2016.03.004

Faff, R. W., \& Howard, P. F. (1999). Interest rate risk of Australian financial sector companies in a period of regulatory change. Pacific-Basin Finance Journal, 7(1), 83-101. doi: https://doi.org/10.1016/S0927-538X(99)00002-5

Ferrando, L., Ferrer, R., \& Jareno, F. (2017). Interest rate sensitivity of Spanish Industries: A quantile regression approach. The Manchester School, 85(2), 212-242. doi: https://doi.org/10.1111/manc.12143

Ferrer, R., Gonzalez, C., \& Soto, G. M. (2010). Linear and nonlinear interest rate exposure in Spain. Managerial Finance, 36, 431-451.

doi: https://doi.org/10.1108/03074351011039445

Hassan, K., Hoque, A., \& Gasbarro, D. (2017). Sovereign default risk linkage: Implication for portfolio diversification. Pacific-Basin Finance Journal, 41, 1-16. doi: https://doi.org/10.1016/j.pacfin.2016.11.002

Halari, A., Tantisantiwong, N., Power, D. M., \& Helliar, C. (2015). Islamic calendar anomalies: Evidence from Pakistani firm-level data. The Quarterly Review of Economics and Finance, 58, 64-73. doi: https://doi.org/10.1016/j.qref.2015.02.004

Hallerbach, W. G. (1994). Theoretical and empirical aspects of the relation between interest rates and common stock returns. In R. L. D'Ecclesia, \& S. A. Zenios (Eds.), Operations research models in quantitative finance (pp. 112-133). Berlin, Germany: Physica-Verlag. doi: https://doi.org/10.1007/978-3-642-46957-2_7

Hamid, K., Akash, R. S. I., \& Ghafoor, M. M. Testing of volatility spillovers dynamics and network connectedness between Islamic indices of regional stock markets. Global Regional Review, 4(1), 1-12.

Hayat, R., \& Hassan, M. K. (2017). Does an Islamic label indicate good corporate governance?. Journal of Corporate Finance, 43, 159-174.

doi: https://doi.org/10.1016/j.jcorpfin.2016.12.012

Hong, K., Lee, J. W., \& Tang, H. C. (2010). Crises in Asia: Historical perspectives and implications. Journal of Asian Economics, 21(3), 265-279.

doi: https://doi.org/10.1016/j.asieco.2009.07.006 
Ibrahim, H. M. (2010). Short-horizon asymmetry in conditional mean of ASEAN Stock market. Asian Academy of Management Journal of Accounting, 6(2), 115-128.

Jareno, F., Ferrer, R., \& Miroslavova, S. (2016). US stock market sensitivity to interest and inflation rates: a quantile regression approach. Applied Economics, 48(26), 2469-2481. doi: https://doi.org/10.1080/00036846.2015.1122735

Joseph, N. L., \& Vezos, P. (2006). The sensitivity of US banks' stock returns to interest rate and exchange rate changes. Managerial Finance, 32(2), 182-199. doi: https://doi.org/10.1108/0307435061064193

Kenourgios, D., Naifar, N., \& Dimitriou, D. (2016). Islamic financial markets and global crises: Contagion or decoupling?. Economic Modelling, 57, 36-46.

doi: https://doi.org/10.1016/j.econmod.2016.04.014

Khawaja, I., Mahmood, T., \& Qadir, U. (2010). Social Impact of Global Recession on Pakistan. Pakistan Economic and Social Review, 48(2), 261-278.

Liau, Y. S., \& Yang, J. J. (2008). The mean volatility asymmetry in Asian stock markets. Applied Financial Economics, 18(5), 411-419.

doi: https://doi.org/10.1080/09603100600959878

Majdoub, J., Mansour, W., \& Jouini, J. (2016). Market integration between conventional and Islamic stock prices. The North American Journal of Economics and Finance, 37, 436-457. doi: https://doi.org/10.1016/j.najef.2016.03.004

Memmel, C. (2011). Banks' exposure to interest rate risk, their earnings from term transformation, and the dynamics of the term structure. Journal of Banking $\mathcal{E}$ Finance, 35(2), 282-289. doi: https://doi.org/10.1016/j.jbankfin.2010.08.003

Merdad, H. J., Hassan, M. K., \& Hippler III, W. J. (2015). The Islamic risk factor in expected stock returns: an empirical study in Saudi Arabia. Pacific-Basin Finance Journal, 34, 293-314. doi: https://doi.org/10.1016/j.pacfin.2015.04.001

Minsky, H. P. (1977). A theory of systemic fragility. In E. I. Altman, \& A. W. Sametz (Eds.), Financial crises, New York, NY: Wiley-Interscience.

Mollah, S., Quoreshi, A. S., \& Zafirov, G. (2016). Equity market contagion during global financial and Eurozone crises: Evidence from a dynamic correlation analysis. Journal of International Financial Markets, Institutions and Money, 41, 151-167. doi: https://doi.org/10.1016/j.intfin.2015.12.010

Nam, K., Pyun, C. S., \& Avard, S. L. (2001). Asymmetric reverting behavior of shorthorizon stock returns: An evidence of stock market overreaction. Journal of Banking $\mathcal{E}$ Finance, 25(4), 807-824. doi: https://doi.org/10.1016/S0378-4266(00)00110-2

Narayan, P. K., \& Bannigidadmath, D. (2017). Does financial news predict stock returns? New evidence from Islamic and non-Islamic stocks. Pacific-Basin Finance Journal, 42, 24-45. doi: https://doi.org/10.1016/j.pacfin.2015.12.009

Oertmann, P., Rendu, C., \& Zimmermann, H. (2000). Interest rate risk of European financial corporations. European Financial Management, 6(4), 459-478.

doi: https://doi.org/10.1111/1468-036X.00135

Oloko, F. T. (2017). Portfolio diversification between developed and developing stock markets: Case of US and UK investors in Nigeria. Research in International Business and Economics, 45, 219-232. doi: https://doi.org/10.1016/j.ribaf.2017.07.153 
Raj, P. A. (2020). Islamic investments a more stable choice in uncertain times. The Endge Markets; A weakly Endge. Retrieved from: https://rb.gy/6hqzo0

Rejeb, A. B. (2017). On the volatility spillover between lslamic and conventional stock markets: A quantile regression analysis. Research in International Business and Finance, 42, 794-815. doi: https://doi.org/10.1016/j.ribaf.2017.07.017

Rashid, A., \& Ahmad, S. (2008). Predicting stock returns volatility: An evaluation of linear vs. nonlinear methods. International Research Journal of Finance and Economics, 20, 141-150.

Saji, T. G. (2013). Time varying macroeconomic risk and industry stock returns: Empirical evidence from India. Asian Journal of Finance $\mathcal{E}$ Accounting, 5(2), 289-304. doi: https://doi.org/10.5296/ajfa.v5i2.4510

Saiti, B., \& Masih, M. (2016). The co-movement of selective conventional and Islamic stock indices: is there any impact on shariah compliant equity investment in China?. International Journal of Economics and Financial Issues, 6(4), 1895-1905.

Sohail, A., \& Javid, A. Y. (2014). The Global Financial Crisis and Investors' Behaviour: Evidence from the Karachi Stock Exchange (Working Paper No: 106). Pakistan Institute of Development Economics, Islamabad, Pakistan.

Shamsuddin, A. (2014). Are Dow Jones Islamic equity indices exposed to interest rate risk?. Economic Modelling, 39, 273-281.

doi: https://doi.org/10.1016/j.econmod.2014.03.007

Usman, M., Jibran, M. A. Q., Amir-ud-Din, R., \& Akhter, W. (2019). Decoupling hypothesis of Islamic stocks: Evidence from copula CoVaR approach. Borsa Istanbul Review, 19, S56-S63. doi: https://doi.org/10.1016/j.bir.2018.09.001

Verhoeven, P., \& McAleer, M. (2004). Fat tails and asymmetry in financial volatility models. Mathematics and Computers in Simulation, 64(3), 351-361. doi: https://doi.org/10.1016/S0378-4754(03)00101-0

Lakshmi, P., Visalakshmi, S., \& Shanmugam, K. (2015). Intensity of shock transmission amid US-BRICS markets. International Journal of Emerging Markets, 10(3), 311-328. doi: https://doi.org/10.1108/IJoEM-04-2013-0063

Wade, R. (2009). Steering out of the crisis. Economic and Political Weekly, 44(13), 39-46.

Wang, L. (2014). Who moves East Asian stock markets? The role of the 2007âĂŞ2009 global financial crisis. Journal of International Financial Markets, Institutions and Money, 28, 182-203. doi: https://doi.org/10.1016/j.intfin.2013.11.003

$\mathrm{Wu}, \mathrm{G}$. (2001). The determinants of asymmetric volatility. The Review of Financial Studies, 14(3), 837-859. doi: https://doi.org/10.1093/rfs/14.3.837

Zhang, B., \& Li, X. (2008). The asymmetric behavior of stock returns and volatilities: Evidence from Chinese stock market. Applied Economics Letters, 15(12), 959-962. doi: https://doi.org/10.1080/13504850600970042 